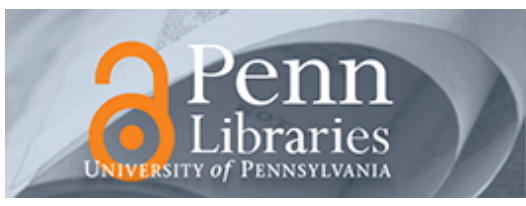

University of Pennsylvania
ScholarlyCommons

Departmental Papers (ASC)

Annenberg School for Communication

2011

\title{
The Effect of Media on Public Knowledge
}

Kathleen Hall Jamieson

University of Pennsylvania, kjamieson@asc.upenn.edu

Bruce W. Hardy

Follow this and additional works at: https://repository.upenn.edu/asc_papers

Part of the Communication Technology and New Media Commons, and the Social Influence and Political Communication Commons

\section{Recommended Citation (OVERRIDE)}

Jamieson, K. H., and Hardy, B. W. (2011). "The Effect of Media on Public Knowledge” in G. C. Edwards III, L. R. Jacobs, and R. Y. Shapiro (eds.), The Oxford Handbook of American Public Opinion and the Media. New York, Oxford University Press.

This paper is posted at ScholarlyCommons. https://repository.upenn.edu/asc_papers/691

For more information, please contact repository@pobox.upenn.edu. 


\section{The Effect of Media on Public Knowledge}

\section{Abstract}

This chapter takes a look at the effect of media on public knowledge, studying the knowledge on the candidates' issue stands and endorsements, and then introducing the concept of the Gas Tax Holiday. It also discusses the effects of partisan media and selective avoidance, along with the informing effect of the Internet.

\section{Keywords}

media, public knowledge, issue stands, endorsements, Gas Tax Holiday, partisan media, selective avoidance, informing effect, Internet

\section{Disciplines}

Communication | Communication Technology and New Media | Social and Behavioral Sciences | Social Influence and Political Communication 


\section{The Effect of Media on Public Knowledge a}

Kathleen Hall Jamieson and Bruce W. Hardy

The Oxford Handbook of American Public Opinion and the Media

Edited by George C. Edwards III, Lawrence R. Jacobs, and Robert Y. Shapiro

Print Publication Date: May 2011 Subject: Political Science, U.S. Politics, Political Behavior

Online Publication Date: Sep 2011 DOI: 10.1093/oxfordhb/9780199545636.003.0015

\section{Abstract and Keywords}

This chapter takes a look at the effect of media on public knowledge, studying the knowledge on the candidates' issue stands and endorsements, and then introducing the concept of the Gas Tax Holiday. It also discusses the effects of partisan media and selective avoidance, along with the informing effect of the Internet.

Keywords: media, public knowledge, issue stands, endorsements, Gas Tax Holiday, partisan media, selective avoidance, informing effect, Internet

THE founders of the United States of America considered the freedom of the press so important that they enshrined its protection in the First Amendment. The reason was simple. "[To] the press alone, chequered as it is with abuses," wrote James Madison, "the world is indebted for all the triumphs which have been gained by reason and humanity, over errors and oppression" (Madison 1799).

The role of the press in preserving democracy is based on the fact that most of us experience politics in digested mediated form. For a body politic populated with individuals preoccupied with earning a living, schooling, raising a family, spending time with friends, and the many demands of life, the press acts as a surrogate. In that role, it flags salient topics and communicates relevant information in palatable form. When the press does not focus on such important matters as the escalating presence of the US in Vietnam in 1964, the vulnerabilities of the Savings and Loan industry in 1988, the January 2001 warnings of the Hart-Rudman Commission about the probability of a terrorist attack on US soil, or the realities underlying the US war in Afghanistan in 2008, the process breaks down.

The press is often viewed as an institution of democracy or the fourth branch of government (Cater 1959). Although a free press is the idealized norm, it is not completely independent from the government as they rely on each other. Government actors depend on the news media to communicate with their constituents and the press relies on the three branches of the government for support from postal subsidies, development of new technologies, and protection of intellectual property. "The news media are an intermediary in- 
stitution in Washington, DC, and a crucial one in a separation-of-powers system where action does not come easily" (Cook 2005, 164).

(p. 237) Although, the news media serve as the conduit between the public and government and are often indicted for their shortcomings, their failure in informing the public is sometimes the outcome of the journalistic norm to legitimize stories with official sources. Journalists "grant government officials a privileged voice in the news" and omit voices that are extreme or fall outside of the "official news gate" (Bennett 1990, 104, 106). According to scholar W. Lance Bennett, from the beat to the boardroom the press "indexes" the official debate (1990). If there is no official debate among "legitimate" voices, there will be little coverage found in mainstream news. Therefore, a failure of the press in alerting the public can be seen as a failure of public officials to stir debate.

What democracy requires is that the press wrangle with topics requiring deliberation, hold those who lead accountable, and communicate accurate information about national affairs in a venue hospitable to debate and the evaluation of alternatives. In a system of government such as ours, this function is a central one because, as Herbert Gans wrote, "The country's democracy may belong directly or indirectly to its citizens, but the democratic process can only be truly meaningful if these citizens are informed" (Gans 2003, 1).

Since US citizens vote for candidates and not policy positions, understanding candidates' stands on issues matters. During presidential elections, we should expect that those who pay reasonable attention to news in its various incarnations will grasp, if not command, the areas of candidate agreement and disagreement. Unsurprisingly, policy preferences influence how people vote (Page and Jones 1979). While the causal direction between embrace of an issue agenda and vote choice is disputed, the fact that they covary is not (Brody and Page 1972).

Although the amount of knowledge voters have about the political system and the issues being disputed in elections fails to satisfy a high ideal (Delli Carpini and Keeter 1996), confusion about candidates' position on issues is not inevitably the fault of the voters. If the media do not cover an issue or do so in ways that minimize learning, then voters must search out the details on their own. The advent of the Internet increases their capacity to do so while at the same time raising the possibility that they will fall prey to misinformation compatible with their ideological dispositions.

Scholars have found that "[although] the possession of 'facts' is related to citizens' media exposure, the correlation is weak, particularly in the case of television news. And once one controls for education level, the correlation nearly disappears" (Patterson and Seib 2005, 191). Exposure to local news actually predicts a drop in political knowledge (Jamieson and Hardy 2007; Prior 2003). Newspaper readership, however, has traditionally been a reliably positive predictor (Becker and Dunwoody 1982; Chaffee and Frank 1996, 48-58; Chaffee, Zhao, and Leshner 1994). So, too, is the use of the Internet to locate political information (Hardy, Jamieson, and Winneg 2008). 
The changed media landscape calls into question findings gathered in an age when newspaper readership was more widespread, when broadcast television news, not cable opinion talk, was the audiovisual form in which most Americans got their political information and the Internet was a gleam in the eyes of a handful of defense contractors and scholars. In October 2008 a Pew survey (Pew Research Center for the People \& the Press 2008) found that television, a category that included cable, was the main source of news for 72 percent of respondents, an increase of 2 percent from 2000. Radio was also a more important source with 21 percent saying that they "got most of their news about the presidential campaign" from that source in 2008 compared with 15 percent who gave the same answer eight years earlier. Reliance on the Internet had tripled with 11 percent turning to it during the Bush-Gore contest and 33 percent reporting the same during the Obama-McCain campaign (Pew Research Center for the People \& the Press 2008).

In light of the past importance of newspapers as a source of accurate information, its drop in readership raises the question we address here. In this changed media world, what is the relationship between media use and command of information useful in casting an informed vote? Some believe that the electorate needs to understand the actual distinctions between candidates. Others hold that shorthand methods are generally reliable and hence desirable in the absence of deeper knowledge. Here we ask how well the media inform about each before turning to an examination of whether, and if so how, public knowledge has been affected by two changes in the media terrain: the use of the remote control in a multichannel world and the advent of partisan media. We begin by examining the relation between media use and issue knowledge and then focus on two more telegraphic forms of information: knowledge of endorsements and awareness of elite consensus.

Overall, the altered landscape has not produced a citizenry dramatically more or less informed that it was two decades ago. “On average, today's citizens are about as able to name their leaders, and are about as aware of major news events, as was the public nearly 20 years ago," reported a Pew survey in 2007 (Pew Research Center for the People \& the Press 2007). That study included "nine questions that are either identical or roughly comparable to questions asked in the late 1980s and early 1990s. In 2007 somewhat fewer were able to name their governor, the vice president, and the president of Russia, but more respondents than in the earlier era gave correct answers to questions pertaining to national politics" (Pew Research Center for the People \& the Press 2007).

\section{Knowledge of Issue Stands of Candidates}

Historically, both heading news and watching debates predicts issue knowledge. In 2004 debate-watching and newspaper-reading predicted knowing the answers to three central questions about the general election candidates' positions on issues (Jamieson and Kenski 2006). Even when education and party identification were controlled, watching a debate significantly increased a citizen's odds of knowing that Kerry was the candidate who favored reimporting drugs from Canada and favored eliminating tax breaks for overseas 
profits of American corporations and using the money to cut taxes for businesses that create jobs in the United States, and that Bush was the candidate (p. 239) who favored allowing workers to invest some of their Social Security contributions in the stock market. Although both were significant, the effect of debate watching on knowledge was stronger than that of newspaper reading.

Evidence from the 2000 National Annenberg Election Study (NAES), however, suggests that media commentary about an event can shape perceptions that differ from those one would hold as a result of actually watching the debate. After the first debate of 2000, assessments of Democratic nominee Al Gore's honesty dropped not among those who actually watched the debate but among those who obtained their information about it from media commentary that focused on putative exaggerations (Erikson 1976; Hollander 1979; Krebs 1998).

\section{Knowledge of Endorsements}

Media exposure also plays a role in informing the public about who supports whom, a form of knowledge that permits voters to draw inferences about the candidates' ideological dispositions or stands on the issues. Endorsements are a useful low-information means of deducing candidate ideology and issue stands. Studies of the effects of newspaper endorsements have produced mixed results. Some have found that they may influence up to 5 percent of the vote (Erikson 1976; Hollander 1979; Krebs 1998). Others conclude that newspaper endorsements have little (Hagen and Jamieson 2000) or no effect at all on vote (Hurd and Singletary 1984; Counts 1985) or only an effect on those less engaged in politics. However, some recent studies of the role of endorsements in the nominating process found significant effects. One that examined "all publicly reported endorsements in a broad range of publications" concluded that "trial-heat" (head-to-head) poll results and endorsements "are almost equally important predictors of primary outcomes" (Cohen, Karol, Noel, and Zaller 2003, 36). A second concluded that such polls and endorsements significantly predict votes in both parties during the primaries (Steger 2007). Endorsements by groups and unions have been shown to drum up enthusiasm among their members (Gimpel 1998), and when an organization or group stands with a candidate, its members are more likely to embrace the endorsee (Burns, Francia, and Herrnson 2000; Rapoport, Stone, and Abramowitz 1991). The effects of endorsements should be more pronounced in primary campaigns in which voters confront candidates about whom they know comparatively little (Kennamer and Chaffee 1982). In intra-party contests, political communication has a unique opportunity to influence independents and party identifiers alike. These effects of course assume that the public knows who endorsed whom, an assumption that raises the question "how does the public obtain that information?"

Data from the 2008 NAES collected during the primary season show that news media consumption was significantly related to knowledge of endorsements (Jamieson and Hardy 2009). The relationship between reported television use and knowledge of endorse- 
ments was particularly strong for the endorsements that a majority of respondents could identify correctly. For example, we found that 79.2 percent of respondents (p. 240) knew that Oprah Winfrey supported Senator Obama and that television information seeking was positively related to knowledge of this endorsement. Similar relationships existed for knowledge of Massachusetts Senator Edward Kennedy and New Mexico Governor Bill Richardson's endorsements of Obama. More than half of respondents were familiar with each, and television news use, newspaper reading, and Internet use were all significantly and positively related to recalling that information.

The New York Times endorsements of Senators Hillary Clinton and John McCain were not as well known as those by Oprah Winfrey, Senator Kennedy, and Governor Richardson. Yet the three news media-use variables-television, newspaper, and Internet-were significantly and positively related to knowing the names of the candidates endorsed by the Times. Media use also predicted awareness of Senator Joe Lieberman's support for McCain, Dr James Dobson's for Huckabee, the United Farm Workers' for Clinton, and MoveOn.org's for Obama. By increasing voter knowledge of endorsements, media provide low-information voters in particular with a form of useful information.

Since the findings are drawn from survey data, strict causal inferences about the impact of news media on knowledge of endorsements are problematic. However, the relationships between news consumption and knowledge of endorsement, reported here, hold in the face of controls such as age, gender, race, education, and ideology, which allows us to be more confident in the relationships (Jamieson and Hardy 2009).

\section{When Consensus is Clear and Communicated by Media it Creates an Effect: The Gas Tax Hol- iday}

Elite consensus functions in much the same way as endorsements. For those who trust it, it minimizes the need for additional information seeking. One set of exchanges in 2008 provided a particularly apt test of the role of media in transmitting elite consensus.

As the last Form 1040s were attached to tax forms on April 15, the presumptive Republican nominee tried to harness his campaign to the news agenda by advocating suspending the federal excise tax on gasoline from Memorial Day to Labor Day. By the end of the month, Democratic contender Hillary Clinton, who remained locked in a tight contest with Barack Obama, was championing the same idea. If, as lay logic but not economic theory suggested, the reduction in the gas tax meant lower prices for consumers, the move would reduce the cost per gallon of gas by the amount of the tax, about 18.4 cents for regular unleaded and 24.4 cents for diesel.

Barack Obama opposed the gas holiday as insistently as McCain and Clinton favored it. In taking the no-tax-holiday position, the Illinois Democrat was on the side of most econo- 


\section{The Effect of Media on Public Knowledge}

mists. Indeed, when pressed, Senator Clinton could not name a single one of that elite class who considered the tax holiday a good idea (ABC News 2008).

(p. 241) On the suspension, the views of economists were clear. "More than 200 economists, including four Nobel Prize winners, signed a letter rejecting proposals by presidential candidates Hillary Clinton and John McCain to offer a summertime gas-tax holiday," noted Brian Faler writing for Bloomberg.com. Opposition crossed party lines:

Columbia University economist Joseph Stiglitz, former Congressional Budget Office Director Alice Rivlin and 2007 Nobel winner Roger Myerson are among those who signed the letter calling proposals to temporarily lift the tax a bad idea. Another is Richard Schmalensee of the Massachusetts Institute of Technology, who was a member of President George H. W. Bush's Council of Economic Advisers....

"Suspending the federal tax on gasoline this summer is a bad idea, and we oppose it," the letter says. Economist Henry Aaron of the Brookings Institution is among those circulating the letter. Aaron said that while he supports Obama, the list includes Republicans and Clinton supporters. (Faler 2008)

Rather than taking on the economists, Senators McCain and Clinton dismissed their views. "I find people who are the wealthiest who are most dismissive of a plan to give low-income Americans a little holiday...Thirty dollars mean nothing to a lot of economists -I understand that. It means a lot to some low-income Americans," Senator McCain responded. When pressed by host George Stephanopoulos on ABC's May 4 This Week to name an economist who supported the gas tax holiday, Clinton responded, "I'm not going to put my lot in with economists."

Included in this controversy were disagreements among political elites (Senator Obama versus Senator Clinton and Senator McCain), intra-party contention (Senator Clinton versus Senator Obama), inter-party contest (Senator Obama versus Senator McCain), and a clash between expert and political elite opinion (Senators McCain and Clinton versus the economists). Put these factors together and you have a test of the scholarly consensus that: (1) expert opinion can influence public opinion; (2) citizens use elite cues to form opinions, with the most politically attentive individuals adopting elite opinion; and (3) elite opinion has the greatest impact on public opinion when there is a consensus among elites (Brody 1991; Darmofal 2005; Yin 1999; Zaller 1992). ${ }^{1}$

According to the 2008 NAES, media use was significantly related to knowledge of the position of the three candidates (Clinton, McCain, and Obama) on the gas tax holiday. ${ }^{2}$ All four of our news media variables-television, talk radio, newspaper, and Internet-were positively related to knowledge of the candidates' stances. ${ }^{3}$ Consistent with past (p. 242) scholarship, 2008 NAES data suggest that the public accepted elite economic opinion and with it the Obama view of the gas tax holiday. The effect of media in priming the elite cue is apparent as television, newspaper, and Internet positively and significantly predicted the belief that gas tax is a bad idea. The media relationships held in the face of controls and after including knowledge of Obama's stance on the gas tax holiday in the model, 


\section{The Effect of Media on Public Knowledge}

which produced a significant and positive relationship with the belief that the gas tax holiday is a bad idea.

We turn next to three changes in the media environment that have affected what people know about politics by altering how they know it. First, we examine the impact of use of the remote control during news viewing; then we turn to an examination of the effects of partisan media on what people know, and close with a discussion on the effect of the Internet and viral email.

\section{Effects of Use of the Remote Control}

The few studies examining channel changing and news content (Morris and Forgette 2007; Walker, Bellamy, and Traudt 1993) used selective avoidance as the theoretical basis explaining motivation for using the remote control during news programs. Past studies have found that 36.5 percent to 59.4 percent of viewers often changed channels to avoid politicians and political ads that they did not like or did not agree with and changed the channel to avoid a news story that they did not like (Walker, Bellamy, and Traudt 1993). Data from a 2004 study conducted by the Pew Research Center found that 62 percent of the public agreed with the statement "I find that I often watch the news with my remote control in hand, flipping to other channels when I'm not interested" (Pew Research Center for the People \& the Press 2004; Morris and Forgette 2007).

These studies focus on shifts from news to non-news content and found this news grazing to be negatively related to levels of political knowledge and positively related to cynicism (Morris and Forgette 2007). Here we are concerned instead with the viewer who switches from one news program to another mid-program.

There is debate over the level of involvement tied to remote control use (Ferguson and Perse 1993; Wang, Busemeyer, and Lang 2006). Some see channel changing as the behavior of an active viewer who is routinely evaluating what she or he is watching and making selections to satisfy certain needs (Walker and Bellamy 1991). Others believe that channel changing is an activity characteristic of the detached and uninvolved viewer, the one nonchalantly "surfing" the channels. A recent study harmonizes these views by suggesting that active and passive viewers reflect different patterns of cognitive effort in processing (Lang et al. 2005) and that remote control use can be active or passive depending on the specific situation. Regardless of level of cognitive involvement in switching channels, we add the reminder that being exposed to multiple and diverse points of views leads to greater acquisition of political knowledge (Scheufele et al. 2004, 2006).

(p. 243) Whatever the effect, according to NAES data collected between August 1 and November 3, 2008, surfing among news channels is common behavior. To identify channel shifters we first asked: "Thinking now about the past week how many days did you see information on broadcast or cable television about the 2008 presidential campaign? This includes seeing programs on television, on the internet, your cellphone, iPod, or PDA." Just over 46 percent (46.6 percent-17,711 respondents) who said that they watched televi-

Page 7 of 16

PRINTED FROM OXFORD HANDBOOKS ONLINE (www.oxfordhandbooks.com). (c Oxford University Press, 2018. All Rights Reserved. Under the terms of the licence agreement, an individual user may print out a PDF of a single chapter of a title in Oxford Handbooks Online for personal use (for details see Privacy Policy and Legal Notice). 
sion news reported such switching among news programs. This level is similar to the numbers found in past research on overall levels of channel changing during any given program (Bellamy and Walker 1996). We find that the positive relationship between channel switching and knowledge of candidate issues stances becomes more robust the more times one switches among programs. These results hold in the presence of stringent controls such as level of education, overall news media use, and interest in the 2008 presidential election.

\section{The Effects of Partisan Media}

Conservative radio and cable were influencing large audiences before their explicitly partisan liberal counterparts, Air America and MSNBC's Countdown with Keith Olbermann and Rachel Maddow show, launched. Rush Limbaugh made his national debut in 1988; Fox News entered the scene eight years later. In 2010 Talkers Magazine put Limbaugh's audience at 15 million and his fellow conservative Sean Hannity's audience at 14 million (Talkers Magazine 2010). A 2004 Pew Center survey found that 22 percent of those in the US get most of their news from Fox. Of those, 46 percent self-identify as conservatives, 32 percent as moderates (Pew Research Center for the People \& the Press 2004).

The presence of explicitly ideological media expanded the public's range of choices and in the process opened the possibility that conservatives would seek out reinforcing information on conservative outlets and liberals would do the same on the other side. Relying on Nielsen's people meter data across sixty-two prominent television networks in the first week of February 2003, media scholar James Webster (2005) found modest evidence of polarization, defined as "the tendency of channel audiences to be composed of devotees and nonviewers." Importantly, Webster's analysis of Fox viewers concluded that "even the audience for FOX News...spends $92.5 \%$ of its time watching something else on television. The rest of their time is widely distributed across the channels they have available" (Webster 2005, 366, 380). "Of course," he adds, "it may be that even a little exposure to certain materials has big social effects, but if these viewers live in cloistered communities, they evidently spend a good deal of time out and about" (Webster 2005, 380). The limitation of analysis by cable network for our purposes is, of course, that where we posit a pattern of reinforcement in exposure to news and opinion talk, these data include both entertainment and non-entertainment programming.

(p. 244) Drawing on Webster's analysis of Nielsen data, political scientist Marcus Prior narrowed the field to focus simply on cable content on networks that program news and opinion talk and notes that "those who watched at least some Fox News spent 7.5\% of their overall viewing time with the Fox News Channel, but another $6 \%$ with the other four cable networks" (CNN, CNN Headline News, CNBC, MSNBC). After analyzing these patterns, he concludes the data "offer little support for claims that the fragmentation of the cable news environment fosters political polarization by encouraging selective exposure to only one side of an issue" (Prior 2007, 157-8). 
Relying on data from the Pew Research Center's 1998 to 2004 Biennial Media Consumption Survey to identify factors predicting exposure to cable and nightly news, Jonathan Morris finds that the audiences for Fox and CNN are becoming increasingly polarized, with Fox viewers less likely than CNN viewers to watch accounts critical of the Bush administration and more likely than non-watchers to underestimate the number of Americans killed in the Iraq War. The study found that "the Fox News audience prefers news that shares their own point of view on politics and issues, while CNN and network news watchers do not" (Morris 2005, 56-79). Similarly, Jamieson and Cappella found that Fox viewers and Limbaugh listeners are more likely than other conservatives to reside in a world in which their view of challenged facts coincided with those of their party (Jamieson and Cappella 2008). The same was true on the other side. CNN's viewers were more likely to accept the liberal view of contested claims.

The process by which this occurs was on display in the Republican primaries of 2008. On his radio show, Rush Limbaugh regularly argued against the candidacies of Senator John McCain and former Arkansas Governor Mike Huckabee and tepidly endorsed former Massachusetts Governor Mitt Romney. During the period between the New Hampshire primary (January 8, 2008) and Super Tuesday (February 5, 2008), Limbaugh strongly attacked McCain's conservative credentials. Those assaults coincided with listeners' perception of McCain, and those who listened to the talk show host were more likely than the non-listening population-including those who describe themselves as conservatives-to believe that McCain was a moderate. The importance of this finding is magnified by its unexpectedness. Limbaugh had vigorously opposed McCain's bid for the Republican nomination in 2000 and reiterated his disdain for the Arizona Republican in the years between 2000 and 2008. In other words, one would have assumed that any effect Limbaugh could have on his listeners had occurred long before he ratcheted up his anti-McCain rhetoric during the 2008 primaries.

The conservative talk show host escalated his attacks on the Republican contender from Arizona in the days before and immediately after McCain's victory in the New Hampshire primary on January 8. As part of his arsenal, Limbaugh repeatedly reminded his listeners that the New York Times had endorsed McCain. Unsurprisingly we found that Limbaugh's listeners were more likely to know about the endorsement than conservatives not in his audience. Controlling for gender, race, education, party identification, and ideology, Limbaugh listeners were 3.94 times more likely than non-listeners to know that the New York Times had endorsed the Arizona senator for the (p. 245) Republican nomination. The New York Times is a frequent object of Limbaugh's attack on the "liberal media."

Controlling for sociopolitical demographic and news media use variables, we see that people's knowledge of McCain's endorsement by the liberal-leaning New York Times editorial page did influence perceptions of McCain's ideological dispositions. Respondents were asked to rate Senator McCain on a five-point scale ranging from "very liberal" to "very conservative." Those who knew about the New York Times endorsement were significantly less likely to see McCain as a conservative. 
An across-time analysis of 639 Limbaugh listeners and 8,077 non-listeners surveyed by the 2008 NAES shows that Rush Limbaugh effectively defined John McCain for his listeners. Before the New Hampshire primary about half of Limbaugh's listeners said McCain was a conservative. That number dropped almost 12 percentage points after McCain won in New Hampshire. After January 8, the number of Limbaugh listeners who said McCain was a liberal jumped 9 percentage points. During this period, the political perceptions of McCain among non-Limbaugh listeners remained stable. An analysis of the differential impact of Limbaugh listening before and after the New Hampshire primaries indicated that Limbaugh had a significant impact on perceptions of McCain's ideological disposition only after the New Hampshire primary.

Immediately after the New Hampshire primary, Limbaugh listeners began to shift from their view that Senator McCain was a conservative. As mentioned above, strict causal claims should not be made. Additionally, any discussion on partisan media needs to take into account selection biases that may be at play as many people are likely to search out views that are in line with their own and don't expose themselves to diverse opinions. Therefore, attitudes, perceptions, and predispositions are likely to be simply reinforced. Yet, these results hold after controlling for gender, race, education, party identification, and respondents' own ideology, suggesting that partisan media have the capacity to increase their audience's awareness of some types of information and to shape the audience's political attitudes (Jamieson and Hardy 2009).

\section{Internet, Knowledge, and the Viral Brew}

In 2004 we found that the Internet, in comparison with traditional press campaign coverage, has an informing effect similar to that of such major campaign events as conventions and debates (Hardy, Jamieson, and Winneg 2008). Following the 2004 general election, the Annenberg Public Policy Center conducted a survey of a random sample of 3,400 citizens to assess the extent to which they believed the many claims made by, or on behalf of, the Bush and Kerry campaigns. In order to test the knowledge of forty-one claims made by the major party campaigns in 2004, respondents rated the accuracy of the claims on a four-point scale ranging from very truthful to not truthful (p. 246) at all. All claims were offered during the course of the campaign. All were checked for accuracy by FactCheck.org, a project of the Annenberg Public Policy Center, which Jamieson and Brooks Jackson direct. We found direct evidence that accessing campaign information online significantly increases citizens' command of fact. We also found that the more respondents believe that the candidates never told the truth in the 2004 election, the more likely they were to turn to the Internet to access campaign information. The cynical voter was likely to turn to the Internet to sort fact from fiction.

The information environment found online transforms the nature of access to the mainstream in ways that increase the chance that using it will produce an effect in the offline world. At very little cost to the citizen, online one can read multiple newspapers and 


\section{The Effect of Media on Public Knowledge}

check multiple news sites in very short order. Information is readily and cheaply accessible, unlike, for example, the cost of subscriptions to a handful of newspapers.

Although we find evidence that citizens can seek and find factual information online, the Internet also facilitates interpersonal communication that is not bounded spatially; this capacity can accelerate the spread of misinformation among citizens quickly through email, instant messaging, and chat rooms without any vetting in the process. There is an added dimension of source heuristics at play here. Receiving a forwarded email from a trusted friend or family member may increase the likelihood of adoption of the deceptive message. The source of the email becomes, in part, the source of the message.

During the 2008 campaign, deceptions spread throughout Internet, including claims that were not extensively discussed in mainstream news or found in candidate ads. One of the more prominent viral deceptive claims of the 2008 campaign suggested that Obama was

a Muslim. This notion was reinforced by another viral claim stating that Obama could not be elected president because he violated the Constitutional requirement that the president be a natural-born citizen. In our post-election deception survey we found that 19 percent believed that Obama was a Muslim. In the presence of demographic, political orientation, media-use controls we found that those who said that they received negative emails about the candidates were more likely to believe Obama is a Muslim than those who did not receive such emails.

\section{Conclusion}

With the proliferation of channels, the Internet and viral email, the rise of explicitly partisan media, and the capacity to channel shift effortlessly across a medium with seven national channels of news and opinion talk, the media landscape has changed dramatically in recent decades. Although the current affairs knowledge of the public has not materially changed as a result, the sources of information contributing to that knowledge have become more varied and the potential to reside in a self-protective enclave of reinforcing information has risen as well.

(p. 247) As technological advances allow users to customize their news repertoirethrough the use of RSS feeds, customized home pages, DVRs, mobile devices, etc....the concept of "mainstream news" will be relegated to the history books. As we have seen in advertising, marketing strategies are shifting away from wide-ranging broadcast messages to focus on niche markets. With the rise of niche information markets, we are seeing the marketplace of ideas go through the same breakup. If these information markets subscribe to different journalistic norms, deliberation over a policy issue between groups may become more difficult as those coming to the table will have incompatible information repertoires.

Future research on the effect of media on public knowledge will need to be highly targeted. No longer will scholars be able to rely on comparing types of media (i.e., newspaper versus television). As citizens now build their own media experiences, researchers will 
need to focus on different communities in the social, not the geographic, sense. Information, and misinformation, flow has become malleable via emails, postings on Facebook, and tweets on Twitter. Effects researchers will need to ask who sent what information to whom in what form through what channel. Like the concept of mainstream media, our scholarly assumptions about the nature and function of media will have to be rethought.

\section{References}

ABC News. 2008. This Week with George Stephanopoulos, May 4.

BECKER, L. B., and DUNWOODY, S. 1982. Media Use, Public Affairs Knowledge and Voting in a Local Election. Journalism Quarterly, 59: 212-18.

BELLAMY, R. V., JR., and WALKER, J. R. 1996. Television and the Remote Control. New York: Guilford Press.

BENNETT, W. L. 1990. Toward a Theory of Press-State Relations in the United States. Journal of Communication, 40/2: 103-27.

BRODY, R. A. 1991. Assessing the President: The Media, Elite Opinion, and Public Support. Stanford, CA: Stanford University Press.

- - and PAGE, B. I. 1972. Comment: The Assessment of Policy Voting. American Political Science Review, 66/2: 450-8.

BURNS, P. F., FRANCIA, P. L., and HERRNSON, P. S. 2000. Labor at Work: Union Campaign Activities and Legislative Payoffs in the U.S. House of Representatives. Social Science Quarterly, 81 : 507-16.

CATER, D. 1959. The Fourth Branch of Government. Boston: Houghton Mifflin.

CHAFFEE, S. H., and FRANK, S. 1996. How Americans Get Political Information: Print versus Broadcast News. Annals of the American Academy of Political and Social Science, 546/1: 48-58.

- Z ZHAO, X., and LESHNER, G. 1994. Political Knowledge and the Campaign Media of 1992. Communication Research, 21: 305-24.

COHEN, M., KAROL, D., NOEL, H., and ZALLER, J. 2003. Polls or Pols? The Real Driving Force behind Presidential Nominations. Brookings Review, 3 (Summer), 36-9.

(p. 248) COOK, T. E. 2005. Governing with the News: The News Media as a Political Institution. Chicago: University of Chicago Press.

COUNTS, T. 1985. Effects of Endorsements on Presidential Vote. Journalism Quarterly, 62 (Autumn), 644-7.

DARMOFAL, D. 2005. Elite Cues and Citizen Disagreement with Expert Opinion. Political Research Quarterly, 58/3: 381-95. 
DELLI CARPINI, M. X., and KEETER, S. 1996. What Americans Know about Politics and Why it Matters. New Haven: Yale University Press.

ERIKSON, R. S. 1976. The Influence of Newspaper Endorsements in Presidential Elections: The Case of 1964. American Journal of Political Science, 20: 207-33.

FALER, B. 2008. Economists Criticize Clinton, McCain Gas-Tax Plans. Bloomberg.com, 5 May. At /http://www.bloomberg.com/apps/news? pid=20601110\&sid=aza2XQB.kk0k $\rangle$. Accessed Oct. 14, 2010.

FERGUSON, D. A., and PERSE, E. M. 1993. Media and Audience Influences on Channel Repertoire. Journal of Broadcasting \& Electronic Media, 37/1: 31-47.

GANS, H. J. 2003. Democracy and the News. Oxford: Oxford University Press.

GIMPEL, J. G. 1998. Packing Heat at the Polls: Gun Ownership, Interest Group Endorsements, and Voting Behavior in Gubernatorial Elections. Social Science Quarterly, 79/3: 634-48.

HAGEN, M. G., and JAMIESON, K. H. 2000. Do Newspaper Endorsements Matter? Do Politicians Speak for Themselves in Newspapers and on Television? In Everything You Think You Know about Politics...And Why You're Wrong, ed. K. H. Jamieson. New York: Basic Books.

HARDY, B. W., JAMIESON, K. H., and WINNEG, K. 2008. The Role of the Internet in Identifying Deception during the 2004 U.S. Presidential Campaign. In Routledge Handbook of Internet Politics, ed. A. Chadwick and P. Howard. London: Taylor \& Francis.

HOLLANDER, S., JR. 1979. On the Strength of a Newspaper Endorsement. Public Opinion Quarterly, 43: 405-7.

HURD, R. E., and SINGLETARY, M. W. 1984. Newspaper Endorsement Influence on the 1980 Presidential Election Vote. Journalism Quarterly, 61 (Summer), 332-8.

JAMIESON, K. H., and CAPPELLA, J. N. 2008. Echo Chamber: Rush Limbaugh and the Conservative Media Establishment. Oxford: Oxford University Press.

- - and HARDY, B. W. 2007. Unmasking Deception: The Capacity, Disposition, and Challenges Facing the Press. In The Politics of News: The News of Politics, ed. D. Graver, D. McQuail, and P. Norris. Washington, DC: CQ Press.

2009. Media, Endorsements and the 2008 Primaries. In Reforming the Presidential Nomination Process, ed. S. S. Smith and M. J. Springer. Washington, DC: Brookings Press.

- - and KENSKI, K. 2006. Issue Knowledge and Perceptions of Agreement in the 2004 Presidential General Election. Presidential Studies Quarterly, 36/2: 243-59. 
-- and WALDMAN, P. 2003. The Press Effect: Politicians, Journalists, and the Stories that Shape the Political World. New York: Oxford University Press.

KENNAMER, D. J., and CHAFFEE, S. H. 1982. Communication of Political Information during the Early Presidential Primaries: Cognition, Affect, and Uncertainty. Communication Yearbook, 5: 627-50.

KREBS, T. B. 1998. The Determinants of Candidates' Vote Share and the Advantages of Incumbency in City Council Elections. American Journal of Political Science, 42: 921-35.

LANG, A., SHIN, M., BRADLEY, S. D., WANG, Z., LEE, S., and POTTER, D. 2005. Wait! Don't Turn that Dial! The Effects of Story Length and Excitement and Production Pacing in Local (p. 249) Television News on Channel Changing Behavior in a Free Choice Environment. Journal of Broadcasting \& Electronic Media, 49: 3-22.

MADISON, J. 1799. The Virginia Report of 1799. At /http://www.constitution.org/rf/ vr_1799.htm $\rangle$. Accessed Oct. 14, 2010.

MORRIS, J. S. 2005. The Fox News Factor. Harvard International Journal of Press/ Politics, 10: 56-79.

-— and FORGETTE, R. 2007. News Grazers, Television News, Political Knowledge, and Engagement. Harvard International Journal of Press/Politics, 12: 91-107.

PAGE, B. I., and JONES, C. C. 1979. Reciprocal Effects of Policy Preferences, Party Loyalties and the Vote. American Political Science Review, 73/4: 1071-89.

PATTERSON, T. E., and SEIB, P. 2005. Informing the Public. In The Press, ed. G. Overholser and K. H. Jamieson. New York: Oxford University Press.

Pew Research Center for the People \& the Press. 2004. News Audiences Increasingly Politicized. Pew, 8 June. At /http://people-press.org/report/215/news-audiences-increasingly-politicized $\rangle$. Accessed Oct. 14, 2010.

- - 2007. Public Knowledge of Current Affairs Little Changed by News and Information Revolutions. Pew, 15 Apr. At /http://people-press.org/report/319/public-knowledgeof-current-affairs-little-changed-by-news-and-information-revolutions $\rangle$. Accessed Oct. 14, 2010.

- - 2008. News Interest Index. Pew, 24-7 Oct. At/http://people-press.org/reports/ questionnaires/466.pdf). Accessed Oct. 14, 2010.

PFAU, M., KENDAL, K. E., REICHERT, T., HELLWEG, S. A., LEE, W., TUSING, K. J., and PROSISE, T. O. 1997. Influence of Communication during the Distant Phase of the 1996 Republican Presidential Primary Campaign. Journal of Communication, 47: 6-26.

POPKIN, S. L. 1994. The Reasoning Voter: Communication and Persuasion in Presidential Campaigns, 2nd edn. Chicago: University of Chicago Press. 
PRIOR, M. 2003. Any Good News in Soft News? The Impact of Soft News Preference on Political Knowledge. Political Communication, 20: 149-71.

- - 2007. Post-Broadcast Democracy: How Media Choices Increases Inequality in Political Involvement and Polarizes Elections. Cambridge: Cambridge University Press.

RAPOPORT, R. B., STONE, W. J., and ABRAMOWITZ, A. I. 1991. Do Endorsements Matter? Group Influence in the 1984 Democratic Caucuses. American Political Science Review, 85: 193-203.

SCHEUFELE, D. A., HARDY, B. W., BROSSARD, D., WAISMEL-MANOR, I. S., and NISBET, E. C. 2006. Democracy Based on Difference: Examining the Links between Structural Heterogeneity, Heterogeneity of Discussion Networks, and Democratic Citizenship. Journal of Communication, 56: 728-53.

—— - NISBET, M. C., BROSSARD, D., and NISBET, E. C. 2004. Social Structure and Citizenship: Examining the Impacts of Social Setting, Network Heterogeneity and Informational Variables on Political Participation. Political Communication, 21: 315-38.

STEGER, W. P. 2007. Who Wins Nominations and Why? An Updated Forecast of the Presidential Primary Vote. Political Research Quarterly, 60: 91-9.

Talkers Magazine. 2010. The Top Talk Radio Audiences (Updated 9/10). At /http:// talkers.com/online/?p=71). Accessed Oct. 14, 2010.

WALKER, J. R., and BELLAMY, R. V., JR. 1991. Gratification of Grazing: An Exploratory Study of Remote Control Use. Journalism Quarterly, 68: 422-31.

and TRAUDT, P. J. 1993. Gratifications Derived from Remote Control Devices: A Survey of Adult RCD Use. In The Remote Control in the New Age of Television, ed. J. R. Walker and R. V. Bellamy, Jr. Westport, CT: Praeger.

(p. 250) WANG, Z., BUSEMEYER, J. R., and LANG, A. 2006. Grazing or Staying Tuned: A Stochastic Model of Channel Changing Behavior. Paper presented at the Annual Meeting of the International Communication Association, International Congress Centre, Dresden.

WEBSTER, J. G. 2005. Beneath the Veneer of Fragmentation: Television Audience Polarization in Multichannel World. Journal of Communication, 55: 366-82.

YIN, J. 1999. Elite Opinion and Media Diffusion: Exploring Environmental Attitudes. Harvard International Journal of Press/Politics, 4/3: 62-86.

ZALLER, J. R. 1992. The Nature and Origin of Mass Opinion. Cambridge: Cambridge University Press. 


\section{Notes:}

(1) Existing studies also suggest that: when elites are divided along party lines, the public becomes polarized; the influence of expert opinion on public opinion is reduced if there is disagreement between expert opinion and political elite opinion with the public following the lead of those whose ideology it shares; and citizens' level of disagreement with experts opinion is in part a function of personal attributes such as education, issue knowledge, and personal experience with the issue.

(2) Exact question wording: "Which candidate or candidates running for president supports suspending the gas tax throughout the summer months this year? (1) Does John McCain support it, or not? (2) Does Hillary Clinton support it, or not? [Deleted June 9, 2008]

(3) Does Barack Obama support it, or not?"

(3) At the $p<.001$ level.

\section{Kathleen Hall Jamieson}

Kathleen Hall Jamieson is Professor at the Annenberg School for Communication at the University of Pennsylvania and Director of its Annenberg Public Policy Center.

\section{Bruce W. Hardy}

Bruce W. Hardy is Senior Research Analyst at the Annenberg Public Policy Center, University of Pennsylvania. 